DIVISION OF THE HUMANITIES AND SOCIAL SCIENCES

CALIFORNIA INSTITUTE OF TECHNOLOGY

PASADENA, CALIFORNIA 91125

HAS THE CROSS-SECTION OF AVERAGE RETURNS

ALWAYS BEEN THE SAME?

EVIDENCE FROM GERMANY, 1881-1913

Peter Bossaerts

Caroline Fohlin

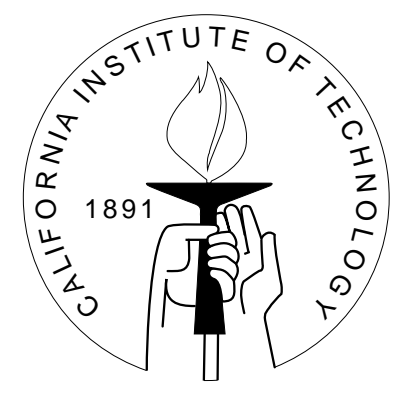

SOCIAL SCIENCE WORKING PAPER 1084 


\title{
Has The Cross-Section of Average Returns Always Been the Same? Evidence from Germany, 1881-1913
}

\author{
Peter Bossaerts Caroline Fohlin
}

\begin{abstract}
The cross-section of average annual returns on German common stock in the period of 1881-1913 exhibits several of the patterns that have been observed in more recent U.S. data. Market beta is hardly important, and its explanatory power is swamped by size and the ratio of book value to market value. A book-to-market risk measure (covariance with a portfolio long in high book-to-market firms and short in low book-to-market firms) has no effect on the explanatory power of the book-to-market characteristic. But the size effect appears to be caused by selection bias in the sample. And the book-to-market effect is opposite that of the recent U.S. experience (and, hence, can certainly not be attributed to selection bias). Finally, a momentum portfolio constructed on the basis of the error of the basic 3-characteristic model (market beta, size and book-to-market) does not generate significant returns. These findings highlight the variability in the power of certain characteristics in explaining the cross section of average returns.
\end{abstract}




\title{
Has The Cross-Section of Average Returns Always Been the Same? Evidence from Germany, 1881-1913*
}

\author{
Peter Bossaerts Caroline Fohlin
}

\section{Introduction}

Since the late sixties, financial economists have been interested in the cross-section of historical average returns on common stock listed on organized exchanges. The interest was sparked by a major theoretical finding, namely, that expected excess returns ought to be proportional to the covariance with the return on the market portfolio. Assuming that the market's expectations are unbiased, this implies that historical average returns in excess of the riskfree rate should be proportional to estimates of "betas" (the covariance with the market portfolio, normalized by the variance of the latter). Soon evidence emerged that this restriction does not hold for common stock listed on the NYSE, AMEX and NASDAQ, and that other characteristics, in particular, size (market capitalization) and the ratio of book value of equity over market value have additional explanatory power, marginalizing the effect of beta. Later, it was found that size and book-to-market reflect risk, because historical average returns on portfolios formed on the basis of size and bookto-market are well explained by the covariance with the market portfolio, the covariance with a portfolio long in small firms and short in large firms (SLM) and the covariance with a portfolio long in firms with high ratios book value to market value of equity and short in firms with correspondingly low ratios (HLM) (Fama and French, 1993 and 1996). This model has become known as the Fama-French 3 -factor model. ${ }^{1}$ Controversy remains, because recent work finds that the book-to-market ratio itself still explains variation in average returns beyond these covariances (Daniel and Titman, 1997 - but see Davis, Fama and French, 2000 for evidence that this is period-specific). That is, the

*Both authors: California Institute of Technology. The financial support of the National Science Foundation and the California Institute of Technology is gratefully acknowledged. Address: $\mathrm{m} / \mathrm{c}$ 228-77, California Institute of Technology, Pasadena, CA 91125; e-mail: pbs@rioja.caltech.edu and fohlin@hss.caltech.edu

${ }^{1}$ As seems to have become standard, we will distinguish between the two approaches as follows: when market beta, size and book-to-market ratio are to explain the cross-section of average returns, we will refer to the "3-characteristic model." If betas with respect to the market, the SLM and HLM portfolio are to explain average returns, then we refer to the " 3 -factor model." 
book-to-market ratio explains part of the error left by the 3-factor model. Moreover, an additional characteristic, momentum, has explanatory power beyond the 3-factor model (Fama and French, 1996). Most of the findings have been corroberated on the basis of evidence from foreign (non-U.S.) stock markets (Fama and French, 1998).

The goal of this paper is to investigate the stability of the relationship between average excess returns and the three traditional characteristics (beta, size, and book-tomarket ratio), the HLM covariance (book-to-market factor), and momentum. Evidence has emerged that the relationship is far from constant (Davis, Fama and French, 2000), and, more specifically, that it varies quite substantially across stock markets in the world (Hawawini and Keim, 1998). Confirmation of this instability would be disturbing, because it would dampen expectations that the alleged patterns across stock returns have useful predictive content. That is, findings for recent American markets may be unable to predict patterns in new, hitherto unexplored markets, or even forecast future patterns in a well-studied market.

The paper studies stock returns in Germany from 1881-1913. The choice of this market is important for two reasons. First, the time period does not overlap with that in studies which discovered the size and book-to-market effect in the U.S. (at most going back to 1929). There is a major methodological advantage of choosing a different time period: there are hardly any informational linkages between the German period under study and the U.S. period commonly analyzed. It could plausibly be argued that size and book-to-market effects have recently been present across different stock markets in the world because they all shared similar information flows (the cold war, increasing importance of international trade in goods and services, common technological breakthroughs, etc.). The informational background against which the German markets operated in the period 1881-1913 was vastly different. If one discovers size and book-tomarket effects there as well, it cannot be claimed anymore that these factors are caused by common information flows.

The choice of location, Germany, is also of importance and raises the second motivation for our selection. While Germany had a different financial intermediation system (universal, relationship banking system), stock markets also played an important role in financing investment-contrary to widespread belief. During the period 1881-1913, the Berlin stock exchange (Berliner Börse), for instance, listed a large and growing number of companies; about one half the number of listed companies on the NYSE as of 1950, for an economy whose size was only a fraction of that of the U.S. of the fifties. Thus, the German case is an important historical case of a financial system that combined strong banks with active securities markets.

This paper addresses the following specific questions. Is there evidence of size or book-to-market effects in the cross-section of average returns on common stock listed on the Berlin exchange in the period 1881-1913? If so, is the nature of the effect the same as in the recent U.S. history (smaller firms outperform larger ones; high book-to-market firms outperform low book-to-market firms)? Are they proxies for risk? Is there any 
momentum effect left after taking into account these effects?

The paper reports results based on the first dataset that has been collected on company-specific historical data for Germany over 1881-1913. It includes annual returns on fifty companies. There is a strong selection bias in this dataset, because companies were selected on the basis of continuous listing during the entire period. Based on the model in Brown, Goetzmann and Ross, 1995, however, we will be able to determine how selection bias could cause the size and book-to-market effects. If only caused by selection bias, however, size and book-to-market effects ought to disappear by 1913. A second dataset is being collected, extending the coverage to monthly returns on 100 firms, selected randomly and without continuous-listing requirement.

In the analysis, we find significant evidence of both a size and book-to-market effect in the German data. It marginalizes the explanatory power of beta. The size effect is of the same direction as in recent U.S. data, but disappears by 1913, suggesting that it was caused by selection bias only. The book-to-market effect is the opposite of that of recent U.S. data (firms with high book value of equity relative to market value experienced lower average returns than those with low ratios, ceteris paribus). The magnitude of the (negative) book-to-market effect remains constant throughout the entire sampling period, indicating that it never picked up selection bias. As in Daniel and Titman, 1997, the book-to-market characteristic captures far more than covariance with the portfolio long in high book-to-market firms and short in low book-to-market firms. When we construct a momentum portfolio based on the error of our 3-characteristic model, we find no evidence significant returns, however.

The remainder of the paper is organized as follows. The next section briefly covers the institutional context of company law and exchange regulations. Section three discusses the methodology and data used; while section four presents the results. The final section draws out some implications of the findings and suggests avenues for further research.

\section{Institutional Background: Company Law and Ex- change Regulations}

There were over 1,000 German joint-stock companies by the early 1870s. ${ }^{2}$ The numbers exceeded 3,000 by 1890 and stayed well over 5,000 from the late 1890's at least until World War I. Throughout the pre-World War I period, a substantial proportion of jointstock firms listed their shares on one or more of the several German stock exchanges. The exchanges also listed many industrial debt securities, particularly those of railway companies (both foreign and domestic).

Most of the issuing of new securities in Germany proceeded through the universal banks. While flotations could be performed by direct subscription of shares (Zeich-

\footnotetext{
${ }^{2}$ This section borrows from Fohlin (2000).
} 
nungsgründung or successive founding), they were, in practice, usually done by the taking over of shares by a promoter or underwriter and subsequent sale of the shares to the public (Übernahmegründung or simultaneous founding). Strict legal stipulations on new issues for example, the requirement that shares be fully paid up before listing may have encouraged this form of new share issuing. The practice also led to the holding of temporary equity stakes by universal bank-underwriters in the firms they floated and may have also increased banks' access to control rights over shares (proxy voting) and to seats on company boards (Ausichtsräte).

Price setting changed comparatively little between 1880 and 1913, though the 1884 and 1896 stock exchange laws formalized certain institutions that were already common practice, at least in Berlin. The exchanges employed two sets of brokers for much of the nineteenth century: private brokers and official brokers (vereidigte Maklern). According to the 1884 law, the latter were appointed for life terms and were legally prohibited from trading on their own accounts or joining with other brokers. The official brokers were responsible for setting securities prices based on the unified price system. Under this procedure, a type of call market, brokers balanced purchase and sale orders and determined, after a round of price announcements and recalculations, the final binding price for all orders placed that day.

Contemporary observers claimed that price setting was not exact or reliable enough and that, in setting the market price, the brokers often followed the wishes of interested bankers, especially when a deal could not be executed on the given day (Wiener, 1905). Indeed, such critics added to the voices calling for reform in the early 1890's. The 1896 law instituted the official brokers (called Kursmaklern) and established the unified price system as the national norm. To the extent that these institutions predated the 1896 law, however, little change in exchange operations would be expected. The new regulations also stipulated that prices be officially set by the exchange directors, in the absence of outsiders (i.e., only the commissioner, secretary, brokers, directors, and representatives of other trades prescribed by exchange regulations were permitted to be present).

\subsection{Previous historical research}

The historical literature has traditionally paid much attention to the role of the universal banking system in the industrialization of Germany, leaving the securities markets relatively unexplored. While some research maintains that the German secondary markets remained largely underdeveloped during even the later stages of industrialization (e.g., Kennedy, 1987, Michie, 1988, and DeLong and Becht, 1992), little empirical evidence has been gathered to support this idea. Interrelations between the universal banking system and securities markets are poorly understood, and the question of market efficiency and the pricing of risk hardly has been raised.

The German experience raises important general issues: first, whether the combination of securities underwriting and trading with commercial banking services naturally 
leads to partial internalization of securities trading within banks, and, second, how such market internalization affects the operation of secondary markets. In investigating the influence of financial institution design on secondary markets, this study goes to the roots of both the universal banking system and the Berlin stock market

The modern literature on the German stock exchanges is extremely sparse; indeed, to our knowledge, nobody has undertaken a study like the one we propose. In a series of papers, Tilly (1986), Kennedy (1991), and Kennedy and Britton (1985) examine portfolio behavior in Germany. Their research, however, emphasizes risk-return tradeoffs and efficient portfolio diversification. The authors, particularly Tilly, hypothesize that the joint provision of investment and commercial services characteristic of the German universal banking system ameliorated problems of asymmetric information and thereby improved risk management.

DeLong and Becht (1992) take a different tack by estimating excess volatility in the Berlin market over the period from 1876 to 1913 and 1951 to 1990. They find that perfect foresight fundamentals overpredict volatility in the pre-war period but underpredict in the more recent period. The results, they speculate, stem from the role of the universal banks in intermediating information and substituting for poorly-developed markets. In particular, they suggest that universal banks were able to convince wary investors of the desirability (stable yields and market values) of the firms the banks promoted and insured this outcome by actively managing share prices. Such was the argument of Prion (1910, 1929), who claimed at least for the latter part of the period that nearly all securities on the exchanges had a "Schutzpatron" (literally, a patron saint), typically a bank, who consulted daily with the exchange brokers on the determination of the price. The postwar appearance of excess volatility, in this view, follows from the demise of the banks' role in the exchanges and the concurrent spread of speculators in the securities markets. In a similar vein, Wetzel (1996) assesses the impact of the 1896 stock exchange law on the efficiency of the Berlin Börse, comparing volatility ratios before and after the ban on futures trading.

\section{Methodology and Data}

\subsection{Methodology}

In order to facilitate easy and comprehensive comparison with results from studies of recent stock market history, we use the Fama-MacBeth methodology when analyzing the cross-section of average returns on the Berlin Börse in the period 1881-1993.

In the first stage of the analysis, we project annual returns onto an intercept, beta,

and size and book-to-market characteristics, producing time series of estimates of four coefficients. (Market betas are estimated in a time series projection of each stock's return onto the return of a proxy of the market portfolio, covering the entire sampling period.) 
We study the (time series) average values of the estimated coefficients in the annual crosssectional projections, as well as their evolution over time. For example, we investigate whether the magnitude of the coefficient of size decrease over time, as would be expected if size picks up selection bias.

In a second stage, we project annual returns onto another risk factor as well, in particular, the covariance with the return on HLM. This will help determine whether the book-to-market characteristic proxies for risk (we will find that size captures selection bias, so that no further analysis needs to be performed).

In a third stage, we study momentum effects. We view momentum as a residual effect. The presence of a momentum effect will be shown to reveal whether there remains unexplained cross-sectional variation in average returns. Hence, momentum works as a diagnostic check, and we compute the average return from a specific momentum portfolio to test whether we have captured all the cross-sectional variation in mean returns. That momentum can potentially provide a diagnostic check is corroborated by Chordia and Shivakumar, 2000, who discovered a statistical model of expected returns that completely eliminated the momentum effect.

Some of the papers that cover the recent U.S. history (e.g., Fama and French, 1996; Daniel and Titman, 1997; Davis, Fama and French, 2000) do not use the Fama-MacBeth methodology. Instead, they use a methodology (Gibbons' methodology) where excess returns are projected onto risk factors (portfolio returns). The effect of characteristics (size, book-to-market ratios) are examined by investigating returns on purposely built portfolios. Gibbons' method has the advantage that it eliminates the estimation error of betas in the first step of the Fama-MacBeth methology. Unlike the Fama-MacBeth methodology, however, it does not force betas to be constant over long periods of time. We opted for the Fama-MacBeth methodology because we are investigating a long time series (21 years) of long-horizon (annual) returns. Moreover, it readily allows one to investigate the additional explanatory power of the book-to-market characteristic by simply adding it in the second step of the Fama-MacBeth procedure, instead of investigating purposely built portfolios, a procedure that has recently been shown to bias the results against a model with risk factors (Berk, 2000).

\subsection{Data Sources}

The current study uses a sample of 50 firms selected by Rettig (1978) and augmented by Fohlin (1998). The time period, 1880-1913, is constrained on the early side by the availability of the necessary financial data and on the later end by World War I. The sample is stratified to represent the regional, sectoral, and size variation of Berlin-listed companies and is restricted to firms in continuous existence (and listing) throughout the period. This last criterion imparts an obvious selection bias to the data, and we discuss this issue at length in the following sub-section. 
The analysis requires several types of data: share prices, dividends, book capitalization, total assets, reserves, and other financial information. Annual share prices, along with the remainder of the necessary data (capitalization, total assets, reserves, annual dividend, and other financial data) come from the annual reports of the companies, reported in both Saling's Börsen-Jahrbuch (part II) and the Handbuch der deutschen Aktiengesellschaften. The former covers all firms listed on the Berlin exchange (beginning in 1876), while the latter reports on every German joint-stock company (beginning in 1895).

The German stock markets and reporting agencies during this period reported share prices as the ratio of the market value to the par value of the share, multiplied by 100 (known as the Kurs). Dividend-adjusted return is the annual percentage change in Kurs plus annual dividends (as a percentage of market value). Dividend-adjusted beta is the coefficient estimate from a regression of dividend-adjusted returns on the dividendadjusted market return (taken from Gielen, 1994). For the current sample, the book value of total equity (the sum of par value of total share capital and reserves) is reported in aggregate, so the total number and par value of shares is not available separately. Thus, market value of equity is calculated as the product of the Kurs and the book value of equity. This method obviously overestimates the market value of all firms. The book-tomarket ratio is calculated as $100 /$ Kurs. Financial performance is the ratio of net income to book equity, and a dummy variable is defined as 1 when the NI/BE ratio is negative and zero otherwise. NI+/BE is equal to NI/BE when positive and zero otherwise.

\subsection{A Digression on Selection Bias}

Our (preliminary) sample has a serious selection bias, because firms are chosen on the basis of continuous listing over the entire sampling period. It is important to study how this may influence a cross-sectional study of average excess returns.

The model in BGIR provides a useful analytical framework. The model assumes that, in the absence of sampling bias, prices follow a geometric Brownian motion with an absorbing lower barrier (to reflect delisting under distress). If, however, sampling is based on continuous listing, the measured process will have markedly different drift (expected return), but the same (mean-zero) stochastic component as the original process. In particular, the following obtains.

- At any point in the sampling period, the bias in the drift is decreasing in the level of the stock price.

- Given a level of the stock price, the bias in the drift decreases over time, and disappears by the end of the sampling period.

- The measurement of risk (covariance with the market portfolio or any other portfolio that reflects aggregate risk) is not affected. 
The last observation holds only locally, i.e., if returns are measured over short intervals. If, however, delisting risk is idiosyncratic (unrelated to aggregate risk), the observation will obtain over longer intervals as well.

What do these findings imply about patterns in the cross-section of average returns of a sample that is affected by selection bias?

- Since size (market capitalization) is highly correlated with the stock price, selection bias will induce the very size effect that is present in recent U.S. data: the average returns (drift) are decreasing in price, and, hence, size.

- Likewise, to the extent that book value over market value of equity correlates (negatively) with price, selection bias will induce the positive book-to-market effect that one observes in recent U.S. data: the average returns are decreasing in price, and, hence, increases in the ratio of book value over market value of equity.

- If the size effect and/or book-to-market effects are caused by selection bias, they ought to disappear by the end of the sampling period.

- To the extent that covariances with the market portfolio, SLM, or HLM reflect aggregate risk that is priced, their effect should show up irrespective of selection biases. E.g., if the covariance with the market portfolio is priced risk, then this should show up in (cross-sectional) projections of excess returns onto market "beta." Likewise, if covariance with the SLM portfolio represents priced risk, then it should show up in the projections.

- There should not be any bias in the estimation of the price of covariance risk. E.g., if covariance with the SLM portfolio is priced risk, it must not disappear over time, unlike the size effect itself (if the latter was caused by selection bias).

- The only effect of continuous-listing selection bias on the cross-sectional prejections of average returns is that it lowers the explanatory power of covariance risk (lower $R^{2} \mathrm{~s}$ ) and it marginalizes its significance.

\subsection{A Digression On Momentum}

Over the last ten years, evidence has been growing that there is a strong momentum effect in U.S. stock returns since the late 1920s. That is, a portfolio long in recent winners and short in recent losers generates significant positive returns. In fact, this momentum effect is to be expected whenever there is any cross-sectional variation in mean returns. Indeed, the expected return on a momentum index is determined directly by the spread (variance) of mean returns in cross-section. To see this, assume that returns are independently and identically distributed over time. Let $R_{n, t}$ denote the return on asset $n$ over period $t$. Let $\mu_{n}$ denote the expected return, assumed constant over time: $\mu_{n}=E\left[R_{n, t}\right]$. Define the momentum portfolio for period $t+1$ as follows. The weight 
on security $n$ is $\left(R_{n, t}-R_{E, t}\right) / N$, where $R_{E, t}$ is the prior-period return on an equally weighted portfolio of all securities. In words, security $n$ receives a weight proportional to how much it outperformed an equally-weighted index in the previous period. Since

$$
\begin{aligned}
& \sum_{n=1}^{N}\left(R_{n, t}-R_{E, t}\right) / N \\
& \quad=\left(\frac{1}{N} \sum_{n=1}^{N} R_{n, t}\right)-R_{E, t} \\
& =R_{E, t}-R_{E, t} \\
& \quad=0,
\end{aligned}
$$

this is a zero-investment portfolio (the weights add up to zero). This also means that the weights ought to be interpreted as number of dollars invested in each security. Next period's (dollar) payoff on the momentum index, $R_{t}^{\text {mom }}$, will be

$$
R_{t}^{\text {mom }}=\sum_{n=1}^{N}\left(R_{n, t}-R_{M, t}\right) R_{n, t+1} / N
$$

The expected payoff is:

$$
\begin{aligned}
& E\left[R_{t}^{\text {mom }}\right] \\
&=E\left[\frac{1}{N} \sum_{n=1}^{N}\left(R_{n, t}-R_{E, t}\right) R_{n, t+1}\right] \\
&=E\left[\frac{1}{N} \sum_{n=1}^{N}\left(R_{n, t}-R_{E, t}\right)\left(R_{n, t+1}-\mu_{n}\right)\right] \\
& \quad+E\left[\frac{1}{N} \sum_{n=1}^{N}\left(R_{n, t}-R_{E, t}\right) \mu_{n}\right] \\
&=\frac{1}{N} \sum_{n=1}^{N} \mu_{n}^{2}-E\left[R_{E, t}\right] \frac{1}{N} \sum_{n=1}^{N} \mu_{n} \\
&=\frac{1}{N} \sum_{n=1}^{N} \mu_{n}^{2}-\left(\frac{1}{N} \sum_{n=1}^{N} \mu_{n}\right)^{2} \\
&>0
\end{aligned}
$$

Consequently, the expected payoff equals the cross-sectional variance of mean returns. If there is any difference in mean returns across securities, the momentum index will generate a positive payoff on average. Therefore, if momentum portfolios have historically generated large positive returns, this proves indirectly that there have been significant differences in mean returns.

We can exploit this mathematical fact to use momentum as a diagnostic check of whether we have explained all the cross-sectional variation in mean returns, as follows. Let $\mu_{n}^{e}$ denote the expected return on security $n$ predicted by our empirical asset pricing 
model (we'll use the three-factor model, where beta, size and book-to-market explains the cross-section of mean returns). Allow for a potential pricing error $\xi_{n}$, where

$$
\xi_{n}=\mu_{n}-\mu_{n}^{e}
$$

Assume that our empirical asset pricing model at least prices securities correctly on average:

$$
\frac{1}{N} \sum_{n=1}^{N} \xi_{n}=0 .
$$

The following momentum portfolio exploits the potential presence of pricing errors, because it will generate significant positive returns if there are indeed pricing errors. Define the weight on security $n$ to be

$$
\left(R_{n, t}-\mu_{n}^{e}\right) / N
$$

It is straightforward to show that this "momentum" index is a zero-investment portfolio. Now compute its expected payoff in excess of what our empirical asset pricing model would predict:

$$
\begin{aligned}
& E\left[\sum_{n=1}^{N}\left(R_{n, t}-\mu_{n}^{e}\right) R_{n, t+1} / N\right]-E\left[\sum_{n=1}^{N}\left(R_{n, t}-\mu_{n}^{e}\right) \mu_{n}^{e} / N\right] \\
& =E\left[\frac{1}{N} \sum_{n=1}^{N}\left(R_{n, t}-\mu_{n}^{e}\right)\left(R_{n, t+1}-\mu_{n}\right)\right] \\
& \quad+E\left[\frac{1}{N} \sum_{n=1}^{N}\left(R_{n, t}-\mu_{n}^{e}\right) \xi_{n}\right] \\
& =E\left[\frac{1}{N} \sum_{n=1}^{N}\left(R_{n, t}-\mu_{n}\right) \xi_{n}\right] \\
& \quad+E\left[\frac{1}{N} \sum_{n=1}^{N}\left(\xi_{n}\right)^{2}\right] \\
& =\quad E\left[\frac{1}{N} \sum_{n=1}^{N}\left(\xi_{n}\right)^{2}\right] \\
& >\quad 0 .
\end{aligned}
$$

The implication is clear: the bigger the mispricing of the asset pricing model, the bigger the outperformance of the momentum index.

The foregoing demonstrates that the performance of specific momentum portfolios can be used as diagnostic test for an asset pricing model. That is, payoffs on momentum indices can be used as the basis of specification tests. We will apply such a test later on.

\section{Results}

Table I provides descriptive statistics of the variables to be used in the cross-sectional analysis of average stock returns. There is enough variation in the explanatory variables 
(market value of equity; book-to-market ratio) for the cross-sectional regressions to be meaningful. One outlier, with returns of $1,303.33$ percent in 1884, was omitted.

Figure 1 plots the time series of dividend-adjusted returns on all 50 firms (dots) and the market index (circles). The spread of the returns on the 50 firms around the return of the market suggests that the 50 firms are typical. There is a survivorship bias in the sample of 50 firms, however. Figure 2 highlights this bias: the average return on the 50 firms is higher than those on the index in earlier years. One could conjecture that part of the difference in average returns may have to be attributed to the fact that the average return on the 50 firms is based on equal weighting, while the market index we use is value weighted. Equal weighting imposes a relatively higher weighting on smaller firms, which in recent U.S. history have outperformed larger firms.

Contrary to this conjecture, however, Table II documents that small firms (quintile 1) in fact had a lower average return ( $7.46 \%$ p.a.) than large firms (quintile 2: $14.03 \%$ p.a.). The numbers in the table are remarkable, when contrasted with recent U.S. data. While small firms are more risky (as measured with standard deviation), they generate smaller average returns. Moreover, unlike in recent U.S. data, there is not a monotonically negative relationship between size and beta. The beta of our largest firms is higher than that of our smallest firms. The middle quintiles generate the lowest betas. Still, like in U.S. data, the book-to-market of the smallest firms is substantially higher than that of other firms. The net income (as percentage of book value of equity) is lower for small firms, indicating that some of them are really firms in distress, as in recent U.S. data (Fama and French, 1995).

Table II also provides descriptive statistics for groups of firms ranked by estimated beta. As in recent U.S. data, there is a slight negative relationship between mean return and beta (we will determine the significance later). There is no relationship between beta and size, unlike in recent U.S. data.

Table III paints a more complete picture of the correlations between the various return and firm characteristics. The slight negative relationship between beta and return reappears, but is insignificant $(p=0.17)$. The correlation between beta and size is positive (unlike in recent U.S. data) and significant $(p<0.01)$, as is the correlation between beta and book-to-market.

As in recent U.S. data, the relationship between return and size is positive, but it is not significant. More striking is the significant, negative correlation between book-tomarket and return: unlike in recent U.S. data, firms with high levels of book value relative to market value of equity generate lower returns.

\subsection{Baseline Multi-Characteristic Models}

Table IV translates all this in the more familiar Fama-Macbeth two-step regression results. Robust-regression and OLS-regression results are displayed, although the differ- 
ences are minor.

The negative, albeit insignificant relation between return and beta is prominent. This confirms findings in recent U.S. data. In multivariate prjections of return onto beta, size and book-to-market, the relation with beta becomes positive, but remains insignificant. The usual size effect appears (small firms generate higher returns on average) and is significant. The book-to-market effect, however, is opposite that of the U.S. The size effect is absorbed by two additional explanatory variables, however: (i) earnings to book value of equity; (ii) earnings (when positive) as a percentage of book value.

The size effect could have been caused by survivorship bias, as explained earlier. The book-to-market effect cannot be attributed to survivorship bias, because it is of opposite sign than expected. If the size effect has indeed been caused by sample bias, we ought to observe a decline over time. Figure 3 plots the evolution of the coefficient in the multivariate regressions of return onto beta, size and book-to-market. The magnitude of the coefficient declines over time, confirming our conjecture that size picks up the survivorhip bias.

There is no evidence that the book-to-market effect changes over time. Figure 4 documents that the coefficient to book-to-market remained equally strong during the entire sampling period. It is negative in all but one year.

The weakness of the relationship between beta and market return might be attributable to estimation error. We estimated betas from the time series of annual returns on each firm individually, instead of assigning betas estimated from groups of betas. Still, the coefficient to beta in the cross-sectional regression of return on beta, size and book-to-market is estimated fairly accurately. In principle, it should recover the actual return on the market index. Figure 5 demonstrates that there is indeed little difference between the estimated coefficients to beta and the annual market return. Because the difference is so small, we might attribute the lack of significance of the average coefficient to the volatility of the market index. However, over the 33-year period, the average return on the market index was $7.6 \%$. With a volatility of $8.7 \%$ p.a., this average is significantly positive at $p<0.01$. Hence, the weakness of the relation between return and beta cannot be attributed to the volatility in the market index. It is very hard to find any evidence of a significant relationship, and, hence, confirm the CAPM; but there is no purely statistical reason for this failure.

\subsection{Book-to-Market Beta}

While the size effect appears to be related to selection bias in our sample, the bookto-market effect is genuine. Consequently, it deserves closer scrutiny. In particular, we should investigate whether the book-to-market ratio proxies for risk. We do this by estimating a second beta, namely, the beta relative to the Fama-French HLM portfolio, and including this beta in the second step of the Fama-MacBeth procedure. If the bookto-market effect reflects risk, it is hoped that it can be captured by the HLM beta. In the 
analysis, we construct the HLM as an equally weighted portfolio, long in the top quintile of firms ranked by book-to-market, and short in firms in the bottom quintile.

The last column in Table IV lists the estimation results in the second step of the Fama-MacBeth procedure. Evidently, the HLM beta has no impact on the book-to-

market effect. Moreover, its coefficient is insignificant on average. This corroborates recent U.S. history (Daniel and Titman, 1997), but is contrary to earlier U.S. history (Davis, Fama and French, 2000).

\subsection{Momentum Portfolio Returns}

To determine whether our 3-characteristic model (market beta, size and book-to-market) captures the cross-sectional variation in mean returns, we implement the momentum portfolio in (??) and test whether its average return is zero. We find that the average annual return is $7.3 \%$. With a standard error of $54 \%$, this is hardly significant $(p=0.23)$.

Figure 6 plots the evolution of the return on this momentum portfolio against that of the market. While the momentum portfolio is more volatile than the market, the lack of significance of its average return cannot be attributed to a few outliers. Only in later years (after 1900) are the returns on the momentum portfolio predominantly positive.

From this result, we conclude that our model captures most of the cross-sectional variation in mean returns.

\section{Conclusion}

We discover several commonalities but also a few differences between recent stock market experience and annual data of returns on common stock listed on the Berlin Börse in the period 1880-1913. In particular, size and book-to-market effects appear prominently, and beta performs weakly, in our models. At the same time, the book-to-market effect runs the opposite of recent experience in the US, and the momentum portfolio yields an insignificant return. In addition, the size effect, since it disappears by the end of the sample period, is attributable to selection bias. While the presence of common effects (e.g., the book-to-market characteristic) might indicate the importance of studying theoretical-perhaps behavioral-explanations, the differences in the magnitude or even direction of these effects suggests they may in fact merely be confounding influences. Theoretical exercises may therefore prove futile in any general sense.

While any comparison across historical periods and locations must be interpreted with care, the parallels and disparities that we find support the conclusion of recent international comparisons of the cross-sectional behavior of returns, namely, that (i) beta, size and book-to-market are important explanatory variables, but (ii) the nature of the relationship between return and these explanatory variables varies. Thus, it appears 
that findings for the US in the post-World War II period have limited predictive power for other markets, and perhaps even for the US itself.

Further research is needed to bolster such conclusions and to help determine the impact of outside influences-such as financial system design or market microstructureon returns. In particular, future work should concentrate on gathering and analyzing larger samples for the German and other non-US markets in the period before World War I as well as studying the US markets themselves in the same period. By placing the German historical experience in perspective with American markets of the same time, we can better distinguish between system effects and time-period effects. 


\section{References}

Allen, F. and D. Gale. (2000) Comparing Financial Systems. Cambridge, MA: MIT Press.

Berk, J.B. (2000) "Sorting Out Sorts." Journal of Finance 55: 407-427.

Brown, S.J., W.N. Goetzmann and S.A. Ross (1995). "Survival." Journal of Finance 50: $853-874$.

Bund der Landwirte. (1908) Das neue Börsengesetz, Berlin.

Buss, G. (1913) Die Berliner Börse von 1685-1913. Berlin: Gedenktage der ersten Versammlung im neuen Hause.

Chordia, T. and K. Shivakumar. (2000). "Momentum, Business Cycle and TimeVarying Expected Returns." Vanderbilt University, Owen School of Management working paper.

Daniel, K. and S. Titman. (1997) "Evidence on the Characteristics of Cross Sectional Variation in Stock Returns." Journal of Finance 52: 1-33.

Davis, J.L., E.F. Fama and K. R. French. (2000) 'Characteristics, Covariances, and Average Returns: 1929 to 1997." Journal of Finance 55: 389-406: 1975-2000.

De Long, B. and M. Becht. (1992) "Excess Volatility and the German Stock Market, 1876-1990. Harvard University Mimeo, Cambridge, MA.

Dermietzel, O. (1906) Statistische Untersuchungen über die Kapitalrente der grösseren deutschen Aktiengesellschaften (mit Ausschluß der Eisenbahnen) von 1876-1902. Göttingen: Louis Hofer.

Donner, O. (1934) "Die Kursbildung am Aktienmarkt," Vierteljahreshefte zur Konjunkturforschung. Berlin: Institut für Konjunkturforschung (Sonderheft 36).

Fama, E. F. and K. R. French. (1992) "The Cross-Section of Expected Stock Returns." Journal of Finance 47: 427-465.

Fama, E. F. and K. R. French. (1993) "Common Risk Factors in the Returns on Stocks and Bonds." Journal of Financial Economics 33: 3-56.

Fama, E. F. and K. R. French. (1996) "Multifactor Explanations of Asset Pricing Anomalies." Journal of Finance 51: 55-84.

Fama, E. F. and K. R. French. (1998) "Value Versus Growth: The International Evidence." Journal of Finance 53: 1975-2000.

Fama, E. F. and J. MacBeth. (1973) "Risk, Return and Equilibrium: Empirical Tests." Journal of Political Economy 81: 607-636. 
Ferson, W. E., S. Sarkissian and T. Simin. (1999) "The alpha factor asset pricing model: A parable." Journal of Financial Markets 2: 49-68.

Fohlin, C. (1999) "Company Law, Stock Exchange Regulation, and the Development of the German Financial System." Social Science Working Paper 1065, California Institute of Technology.

Freixas, X. and J-C Rochet. (1997) Microeconomics of Banking. Cambridge, MA: MIT Press.

Gielen, G. (1994) Können Aktienkurse noch steigen? Langfristige Trendanalyse des deutschen Aktienmarktes. Weisbaden, Germany: Der Gabler Verlag.

Gömmel, R. (1992) "Entstehung und Entwicklung der Effektenbörse im 19. Jahrhundert bis 1914." In Deutsche Böengeschichte, edited by H. Pohl. Frankfurt.

Handbuch der Deutschen Aktiengesellschaaften, various years.

Kennedy, W. P. (1987) Industrial Structure, Capital Markets and the Origins of British Economic Decline. London: Cambridge University Press.

Kennedy, W. P. (1991) "Portfolio Behavior and Economic Development in Late NineteenthCentury Great Britain and Germany: Hypotheses and Conjectures." Research in Economic History 6: 93-130.

Kennedy, W. P. and R. Britton. (1985) "Portfolioverhalten und wirtschaftliche Entwicklung im späten 19. Jahrhundert. Ein Vergleich zwischen Großbritannien und Deutschland. Hypothesen und Spekulationen." In Richard Tilly (Ed.), Beiträge zur quantitativen vergleichenden Unternehmensgeschichte. Stuttgart.

Liefmann, R. (1921) Beteiligungs- und Finanzierungsgesellschaften.

Magill, M. and M. Quinzii. (1998) "Equity Options and Efficiency in the Presence of Moral Hazard." USC Working Paper.

Magill, M. and M. Quinzii. (1999) "Incentives and Risk Sharing in a Stock Market Equlibrium." USC Working Paper.

Marx, E. (1913) Die Entwicklung der deutschen Provinzbörsen. Berlin.

Meier, J-C. (1993) Die Entstehung des Börsengesetzes vom 22. Juni 1896. Vol. 9. Studien zur Wirtschafts- und Sozialgeschichte. München, Germany: St . Katharinen.

Michie, R. (1988) "Different in Name Only? The London Stock Exchange and Foreign Bourses, c. 1850-1914." Business History 30: 46-68.

Pohl, M. (1982) Konzentration im deutschen Bankwesen, 1848-1980. Frankfurt.

Prion, W. (1910) Die Preisbildung an der Wertpapierbörse. Liepzig: Verlag von Duncker \& Humblot. 
Prion, W. (1929) Die Preisbildung an der Wertpapierbörse. München: Verlag von Duncker \& Humblot.

Riesser, J. (1910) Die deutschen Großbanken und ihre Konzentration, Jena: Verlag von Gustav Fischer. [English translation: (1911) The German Great Banks and their Concentration. Published by The National Monetary Commission (Washington: Government Printing Office).]

Schulz, W. (1994) Das deutsche Börsengesetz. Die Entstehungsgeschichte und wirtschaftlichen Auswirkungen des Börsengesetzes von 1896. Frankfurt: Peter Lang.

Stillich, O. (1909) Die Börse und ihre Geschäfte. Berlin.

Taeuber, R. (1911) Die Börsen der Welt. Berlin: Verlag für Börsen- und Finanzliteratur A.-G.

Tilly, R. (1986) "German Banking, 1850-1914: Development Assistance to the Strong." Journal of European Economic History 15: 113-52.

Tilly, R. (1995) "The Berlin Securities Exchange in National Context: Actors, Rules and Reforms to 1914." Working paper, University of Münster, Germany.

Weber, A. (1915) Depositenbanken und Spekulationsbanken, second edition, Leipzig: Duncker \& Humblot.

Wetzel, C. (1996) Die Auswirkungen des Reichsbörsengesetzes von 1896 auf die Effektenbörsen im Deutschen Reich, insbesondere auf die Berliner Fondsbörse. Münster, Germany: Lit Verlag.

Wiener, F. A. (1905) Die Börse, Dissertation: Berlin.

Whale, P. B. (1930) Joint-Stock Banking in Germany. London: MacMillan and Co. 
Table I

Size, Book-to-Market Ratio, and Returns: 50 Long-Lived Firms, 1880-1913

Market equity is the price of shares times the book value of shares and reserves. B/M ratio is book value of equity divided by market value of equity. Dividend-adjusted return is the percentage increase in share price plus dividend (as percent of market value) and omits one observation of 1,303.33 percent in 1884. Marks during this time can be multiplied by three to obtain a rough estimate of 2000 dollar values. (Source: Saling's Börsen-Jahrbuch (1881-1914); from Rettig (1978) and Fohlin (1994)).

\begin{tabular}{|c|c|c|c|c|c|c|c|c|c|c|c|c|}
\hline \multirow[t]{2}{*}{ year } & \multicolumn{4}{|c|}{$\begin{array}{c}\text { Market equity } \\
\text { (millions of marks) }\end{array}$} & \multicolumn{4}{|c|}{ Book-to-market ratio } & \multicolumn{4}{|c|}{$\begin{array}{l}\text { Dividend-adjusted returns } \\
\text { (percent per annum) }\end{array}$} \\
\hline & avg & $\mathrm{sd}$ & $\min$ & $\max$ & avg & $\mathrm{sd}$ & $\min$ & $\max$ & avg & $\mathrm{sd}$ & $\min$ & $\max$ \\
\hline 1880 & 4.99 & 6.39 & 0.31 & 28.88 & 1.55 & 1.45 & 0.57 & 9.30 & - & - & - & \\
\hline 1881 & 5.64 & 7.46 & 0.22 & & & 2.10 & 0.53 & 13.79 & 16.50 & 23.95 & -32.56 & 91.50 \\
\hline 1882 & 6.71 & 8.95 & 0.13 & 41.33 & 1.68 & 3.75 & 0.55 & 25.64 & 17.86 & 27.09 & -46.21 & 94.33 \\
\hline 1883 & 7.11 & 9.00 & 0.09 & 40.02 & 1.77 & 4.85 & 0.50 & 33.33 & 14.87 & 20.87 & -23.08 & 66.69 \\
\hline 1884 & 7.80 & 9.70 & 0.31 & 38.97 & 0.97 & 0.56 & 0.42 & 2.38 & 14.22 & 25.34 & -41.14 & 82.80 \\
\hline 1885 & 7.84 & 9.82 & 0.33 & 41.56 & 1.05 & 0.64 & 0.37 & 3.22 & 7.49 & 14.70 & -26.13 & 41.03 \\
\hline 1886 & 8.89 & 11.73 & 0.54 & 53.13 & 0.92 & 0.53 & 0.17 & 2.78 & 22.35 & 35.23 & -30.49 & 154.93 \\
\hline 1887 & 8.67 & 11.38 & 0.49 & 47.67 & 1.02 & 0.66 & 0.27 & 3.57 & 4.89 & 19.75 & -47.17 & 57.13 \\
\hline 1888 & 0.86 & 12.89 & 0.69 & 60.26 & 0.79 & 0.53 & 0.26 & 3.51 & 33.07 & 29.58 & -7.38 & 127.62 \\
\hline 1889 & 14.60 & 20.21 & 1.06 & 107.29 & 0.68 & 0.29 & 0.26 & 1.51 & 28.79 & 49.78 & -20.14 & 296.49 \\
\hline 1890 & 14.51 & 19.28 & 0.92 & 79.00 & 0.80 & 0.37 & 0.27 & 1.72 & -5.50 & 16.07 & -44.47 & 25.32 \\
\hline 1891 & 2.41 & 15.66 & 0.69 & 65.42 & 0.97 & 0.57 & 0.40 & 3.70 & -3.63 & 16.05 & -52.53 & 30.58 \\
\hline 1892 & .41 & 13.87 & 0.51 & 54.96 & 0.92 & 0.45 & 0.31 & 2.36 & 14.43 & 39.69 & -39.43 & 236.41 \\
\hline 1893 & & 15.93 & 0.36 & & 93 & 54 & 0.31 & & 11.74 & 13.76 & -27.42 & 40.59 \\
\hline 1894 & .48 & 16.79 & 0.36 & & 0.82 & 0.46 & 0.26 & 2.90 & 19.47 & 21.80 & -36.92 & 91.50 \\
\hline 1895 & 15.49 & 19.92 & 0.94 & 82.87 & 0.71 & 0.37 & 0.22 & 2.38 & 21.75 & 15.87 & -5.31 & 61.55 \\
\hline 1896 & 17.85 & 23.48 & 0.41 & 93.88 & 0.66 & 0.33 & 0.19 & 2.17 & 18.20 & 14.46 & -12.38 & 52.06 \\
\hline 1897 & 20.92 & 30.66 & 0.56 & & 0.66 & & 0.21 & 1.50 & 16.52 & 20.51 & -36.08 & 69.39 \\
\hline 1898 & 24.79 & 39.61 & 0.45 & 176.56 & 0.65 & 0.33 & 0.21 & 1.59 & 13.80 & 15.74 & -18.51 & 74.62 \\
\hline 1899 & 28.26 & 44.13 & 0.56 & 210.41 & 0.63 & 0.32 & 0.21 & 1.79 & 13.99 & 18.35 & -37.34 & 77.82 \\
\hline 1900 & 24.37 & 38.15 & 0.40 & 161.13 & 0.72 & 0.34 & 0.20 & 1.63 & 0.65 & 15.30 & -32.04 & 50.15 \\
\hline 1901 & +.00 & 38.34 & 0.52 & 174.17 & 0.78 & 0.38 & 0.22 & 1.84 & 1.21 & 12.91 & -24.99 & 35.78 \\
\hline 1902 & 26.68 & 41.19 & 0.34 & & 0.73 & 0.36 & 0.21 & 1.79 & 14.82 & 14.28 & -9.29 & 60.26 \\
\hline 1903 & 30.88 & 47.74 & 0.37 & 189.62 & 0.70 & 0.37 & 0.17 & 1.83 & 18.91 & 15.54 & -10.89 & 59.38 \\
\hline 1904 & 34.16 & 54.10 & 0.57 & 246.99 & 0.64 & 0.36 & 0.17 & 1.86 & 19.42 & 17.08 & -20.33 & 57.23 \\
\hline 1905 & 36.68 & 57.41 & 0.56 & 241.73 & 0.60 & 0.33 & 0.19 & 1.61 & 14.00 & 12.31 & -21.21 & 45.82 \\
\hline 1906 & & 63.26 & 0.61 & & 0.62 & 0.35 & 0.18 & & 10.81 & 15.67 & -42.10 & 45.39 \\
\hline 1907 & 35.78 & 57.27 & 0.42 & 269.79 & 0.69 & 0.38 & 0.19 & 2.25 & 0.15 & 15.39 & -33.02 & 50.71 \\
\hline 1908 & 36.26 & 61.16 & 0.35 & 301.53 & 0.73 & 0.47 & 0.20 & 2.70 & 8.46 & 18.09 & -50.34 & 45.25 \\
\hline 1909 & 41.47 & 67.26 & 0.45 & 311.17 & 0.63 & 0.34 & 0.18 & 1.95 & 20.28 & 13.51 & -19.42 & 52.62 \\
\hline 1910 & 39.91 & 68.77 & 0.41 & 360.32 & 0.67 & 0.33 & 0.25 & 1.59 & 7.02 & 12.94 & -23.11 & 32.33 \\
\hline 1911 & 45.71 & 82.30 & 0.42 & 472.59 & 0.67 & 0.41 & 0.18 & 2.19 & 10.78 & 17.70 & -32.29 & 76.62 \\
\hline 1912 & 43.55 & 79.27 & 0.45 & 464.03 & 0.78 & 0.64 & 0.20 & 3.64 & 0.28 & 14.75 & -44.78 & 28.59 \\
\hline 1913 & 46.43 & 92.79 & 0.30 & 582.30 & 0.88 & 0.96 & 0.20 & 6.62 & 7.37 & 23.83 & -52.81 & 98.18 \\
\hline years & 22.81 & 45.30 & 0.09 & 582.30 & 0.86 & 1.21 & 0.17 & 33.33 & 12.51 & 22.90 & -52.81 & 296.49 \\
\hline
\end{tabular}




\section{Table II}

\section{Descriptive Statistics by Size and Beta Ranking}

In panel A, the sample is divided into five groups of ten firms each, ranked in increasing order of size (measured as market value of equity). In panel B, the firms are similarly ranked based on dividend-adjusted beta. One outlier firm is eliminated from the sample (size rank 1 and beta rank 5). B/M ratio is book value of equity divided by market value of equity. Dividend-adjusted return is the percentage increase in share price plus dividend (as percent of market value).

\begin{tabular}{|c|c|c|c|c|c|c|c|c|c|c|}
\hline \multirow[t]{2}{*}{ Panel A: Ranked by size } & \multicolumn{2}{|l|}{1} & \multicolumn{2}{|l|}{2} & \multicolumn{2}{|l|}{3} & \multicolumn{2}{|l|}{4} & \multicolumn{2}{|l|}{5} \\
\hline & mean & $\mathrm{sd}$ & mean & $\mathrm{sd}$ & mean & $\mathrm{sd}$ & mean & sd & mean & $\mathrm{sd}$ \\
\hline Dividend-adjusted returns & 7.46 & 34.07 & 14.45 & 19.43 & 11.87 & 14.44 & 15.14 & 20.23 & 14.03 & 20.01 \\
\hline Dividend-adjusted beta & 1.26 & 1.17 & 0.60 & 0.42 & 0.70 & 0.41 & 0.61 & 0.59 & 1.46 & 0.85 \\
\hline Ln(market equity) & 14.21 & 0.63 & 15.31 & 0.62 & 15.82 & 0.74 & 16.65 & 0.75 & 17.78 & 1.01 \\
\hline Market equity (millions of marks) & 1.77 & 1.01 & 5.26 & 2.93 & 9.30 & 5.56 & 22.30 & 17.23 & 81.68 & 79.84 \\
\hline Ln(book-to-market) & 0.19 & 0.42 & -0.33 & 0.48 & -0.53 & 0.42 & -0.63 & 0.49 & -0.58 & 0.43 \\
\hline Book-to-market & 1.33 & 0.67 & 0.81 & 0.47 & 0.64 & 0.27 & 0.60 & 0.33 & 0.62 & 0.31 \\
\hline Net income/book equity & 0.05 & 0.10 & 0.11 & 0.08 & 0.10 & 0.06 & 0.12 & 0.08 & 0.10 & 0.05 \\
\hline Dummy variable $(\mathrm{NI} / \mathrm{BE}$ neg=1) & 0.09 & 0.29 & 0.01 & 0.08 & 0.01 & 0.09 & 0.01 & 0.09 & 0.01 & 0.11 \\
\hline $\mathrm{NI}+/ \mathrm{BE}$ & 0.06 & 0.08 & 0.11 & 0.08 & 0.11 & 0.06 & 0.12 & 0.07 & 0.10 & 0.05 \\
\hline Average $\mathrm{N}$ & 290 & & 338 & & 324 & & 332 & & 305 & \\
\hline \multirow[t]{2}{*}{ Panel B: Ranked by beta } & 1 & & 2 & & 3 & & 4 & & 5 & \\
\hline & mean & $\mathrm{sd}$ & mean & sd & mean & $\mathrm{sd}$ & mean & sd & mean & sd \\
\hline Dividend-adjusted returns & 16.25 & 24.53 & 9.38 & 17.68 & 14.80 & 16.83 & 11.89 & 20.09 & 10.75 & 31.31 \\
\hline Dividend-adjusted beta & 0.06 & 0.19 & 0.49 & 0.12 & 0.82 & 0.12 & 1.17 & 0.14 & 2.27 & 0.87 \\
\hline $\operatorname{Ln}($ market equity) & 15.83 & 1.02 & 15.70 & 1.45 & 16.08 & 1.26 & 16.29 & 1.43 & 15.86 & 1.75 \\
\hline Market equity (millions of marks) & 11.98 & 12.13 & 20.84 & 42.05 & 20.56 & 29.44 & 36.12 & 72.42 & 28.58 & 48.42 \\
\hline Ln(book-to-market) & -0.51 & 0.57 & -0.36 & 0.41 & -0.46 & 0.56 & -0.43 & 0.50 & -0.10 & 0.54 \\
\hline Book-to-market & 0.70 & 0.42 & 0.77 & 0.40 & 0.75 & 0.51 & 0.75 & 0.54 & 1.05 & 0.59 \\
\hline Net income/book equity & 0.11 & 0.08 & 0.09 & 0.06 & 0.11 & 0.06 & 0.10 & 0.07 & 0.07 & 0.10 \\
\hline Dummy variable (NI/BE neg=1) & 0.02 & 0.15 & 0.01 & 0.11 & 0.00 & 0.05 & 0.03 & 0.18 & 0.06 & 0.23 \\
\hline $\mathrm{NI}+/ \mathrm{BE}$ & 0.12 & 0.08 & 0.09 & 0.06 & 0.11 & 0.06 & 0.10 & 0.06 & 0.08 & 0.08 \\
\hline Average $\mathrm{N}$ & 335 & & 329 & & 335 & & 313 & & 275 & \\
\hline
\end{tabular}


Table III

Pairwise Correlation Coefficients for Pooled Cross Section-Time Series

Significance levels of correlation coefficients are in italics. The bottom number in each row is the number of observations available for each correlation. One outlier firm is removed. B/M ratio is book value of equity divided by market value of equity. Dividendadjusted return is the percentage increase in share price plus dividend (as percent of market value).

\begin{tabular}{lrrrr}
\hline & $\begin{array}{r}\text { Dividend- } \\
\text { adjusted return }\end{array}$ & $\begin{array}{r}\text { Dividend- } \\
\text { adjusted beta }\end{array}$ & $\begin{array}{r}\text { Market value of } \\
\text { equity }\end{array}$ & $\begin{array}{r}\text { Book-to-market } \\
\text { value of equity }\end{array}$ \\
\hline Dividend-adjusted beta & -0.04 & & & \\
& 0.17 & & & \\
Market value of equity & 1,480 & & & \\
& 0.02 & 0.17 & & \\
Book-to-market value of & 0.54 & 0.00 & & \\
equity & 1,480 & 1,557 & & \\
& -0.33 & 0.21 & 0.25 & \\
Net income/book equity & 0.00 & 0.00 & 0.00 & -0.57 \\
& 1,480 & 1,557 & 1,557 & 0.00 \\
& 0.46 & -0.17 & 0.05 & 1,556 \\
\hline
\end{tabular}




\section{Table IV}

\section{Average Coefficient Estimates from Annual Cross-Section Regressions}

Coefficients are averages over annual observations. All models include a constant (not reported). P-values of one-sided t-tests are in italics below coefficient means. Beta is estimated for each firm over the full period. ME is the market value of equity, and $\mathrm{BE} / \mathrm{ME}$ is the ratio of book-to-market values of equity. $\mathrm{E} / \mathrm{BE}$ is the ratio of net income to book value of equity. E/BE dummy is one when $\mathrm{E} / \mathrm{BE}$ is negative and zero otherwise. $\mathrm{E}(+) / \mathrm{BE}$ is equal to $\mathrm{E} / \mathrm{BE}$ when that value is positive and is zero otherwise. Robust in the column heading indicates the use of a limited-influence estimator (Huber/bi-weight) in the underlying cross-sectional regressions. The estimator is described in the text.

\begin{tabular}{|c|c|c|c|c|c|}
\hline & Robust & OLS & Robust & Robust & Robust \\
\hline Beta & $\begin{array}{r}-0.90 \\
0.27\end{array}$ & $\begin{array}{l}1.88 \\
0.17\end{array}$ & $\begin{array}{l}1.84 \\
0.09\end{array}$ & $\begin{array}{l}1.42 \\
0.15\end{array}$ & $\begin{array}{l}1.08 \\
0.21\end{array}$ \\
\hline $\ln (\mathrm{ME})$ & & $\begin{array}{r}-1.96 \\
0.00\end{array}$ & $\begin{array}{r}-1.43 \\
0.00\end{array}$ & $\begin{array}{r}-0.36 \\
0.19\end{array}$ & $\begin{array}{r}-1.24 \\
0.00\end{array}$ \\
\hline $\ln (\mathrm{BE} / \mathrm{ME})$ & & $\begin{array}{r}-18.83 \\
0.00\end{array}$ & $\begin{array}{r}-19.44 \\
0.00\end{array}$ & $\begin{array}{r}-8.50 \\
0.00\end{array}$ & $\begin{array}{r}-19.26 \\
0.00\end{array}$ \\
\hline E/BE dummy & & & & $\begin{array}{r}-7.80 \\
0.01\end{array}$ & \\
\hline $\mathrm{E}(+) / \mathrm{BE}$ & & & & $\begin{array}{r}76.36 \\
0.00\end{array}$ & \\
\hline Beta (BM beta) & & & & & $\begin{array}{l}1.50 \\
0.20\end{array}$ \\
\hline
\end{tabular}




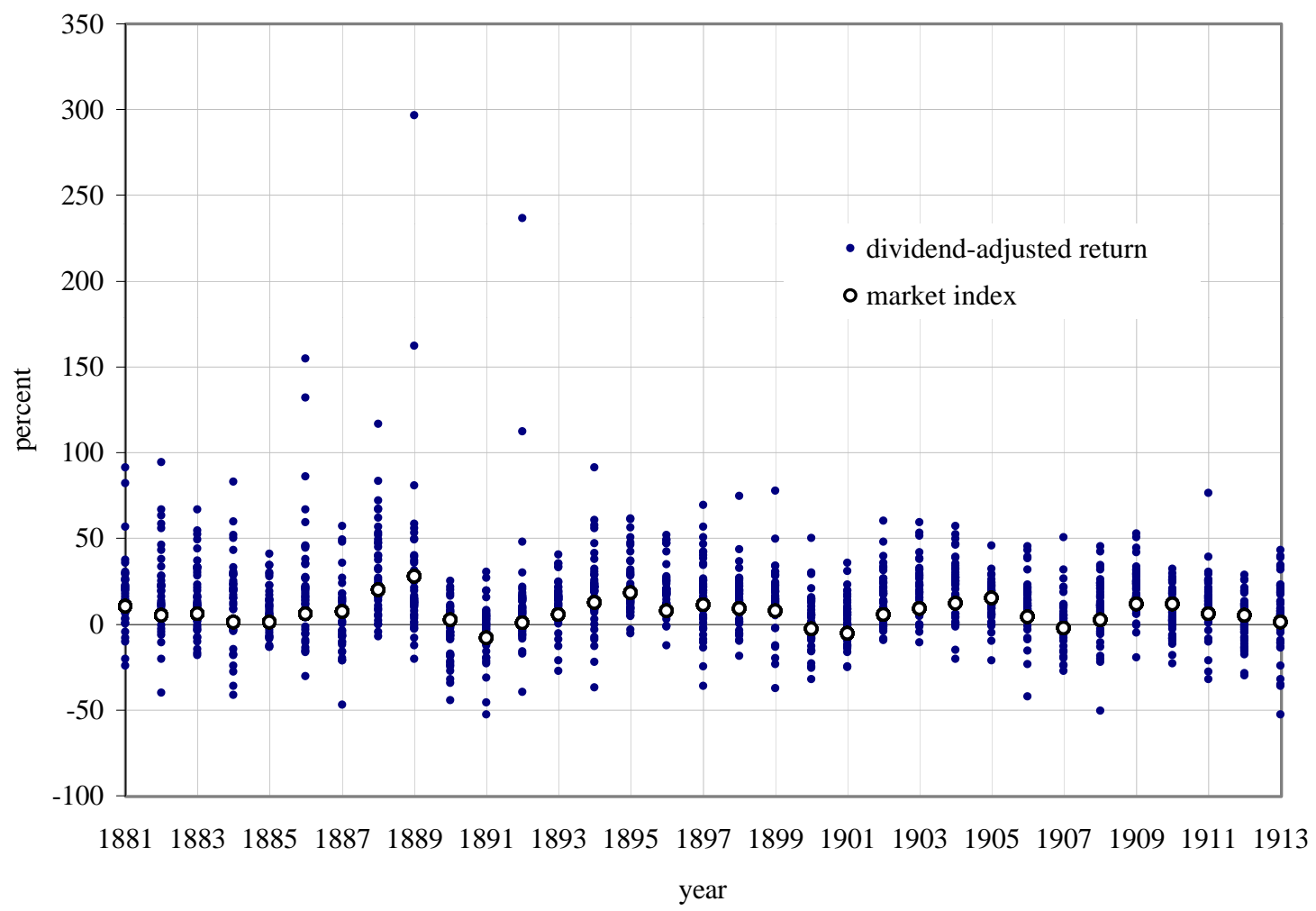

Figure 1. Dividend-Adjusted Returns. This figure presents the dividend-adjusted returns on the sample of 50 long-lived firms as well as on the market index. 


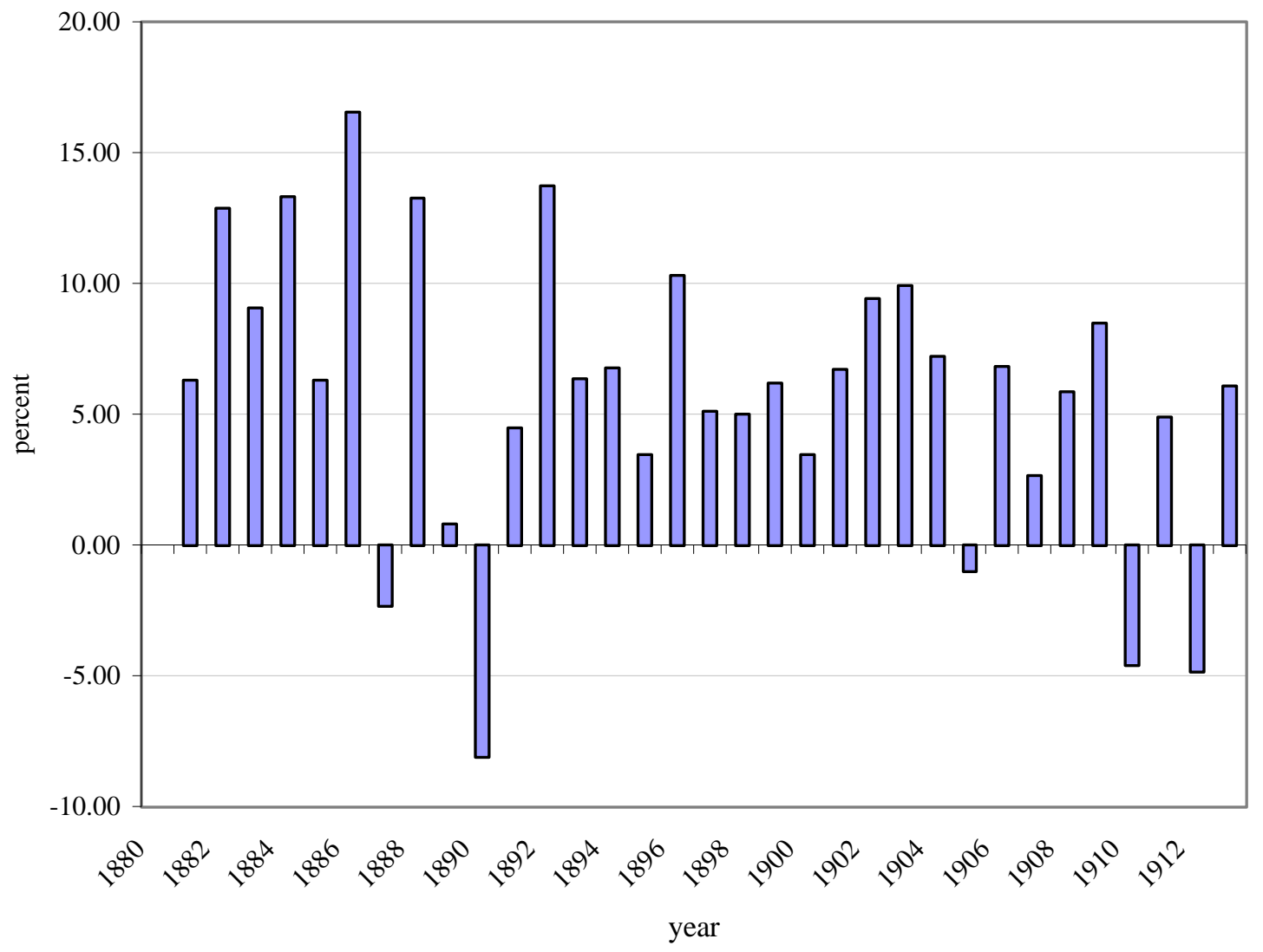

Figure 2. Difference in Average Dividend-Adjusted Returns. This figure presents the difference between average annual dividend-adjusted returns for the sample of 50 long-lived firms and the market portfolio. 


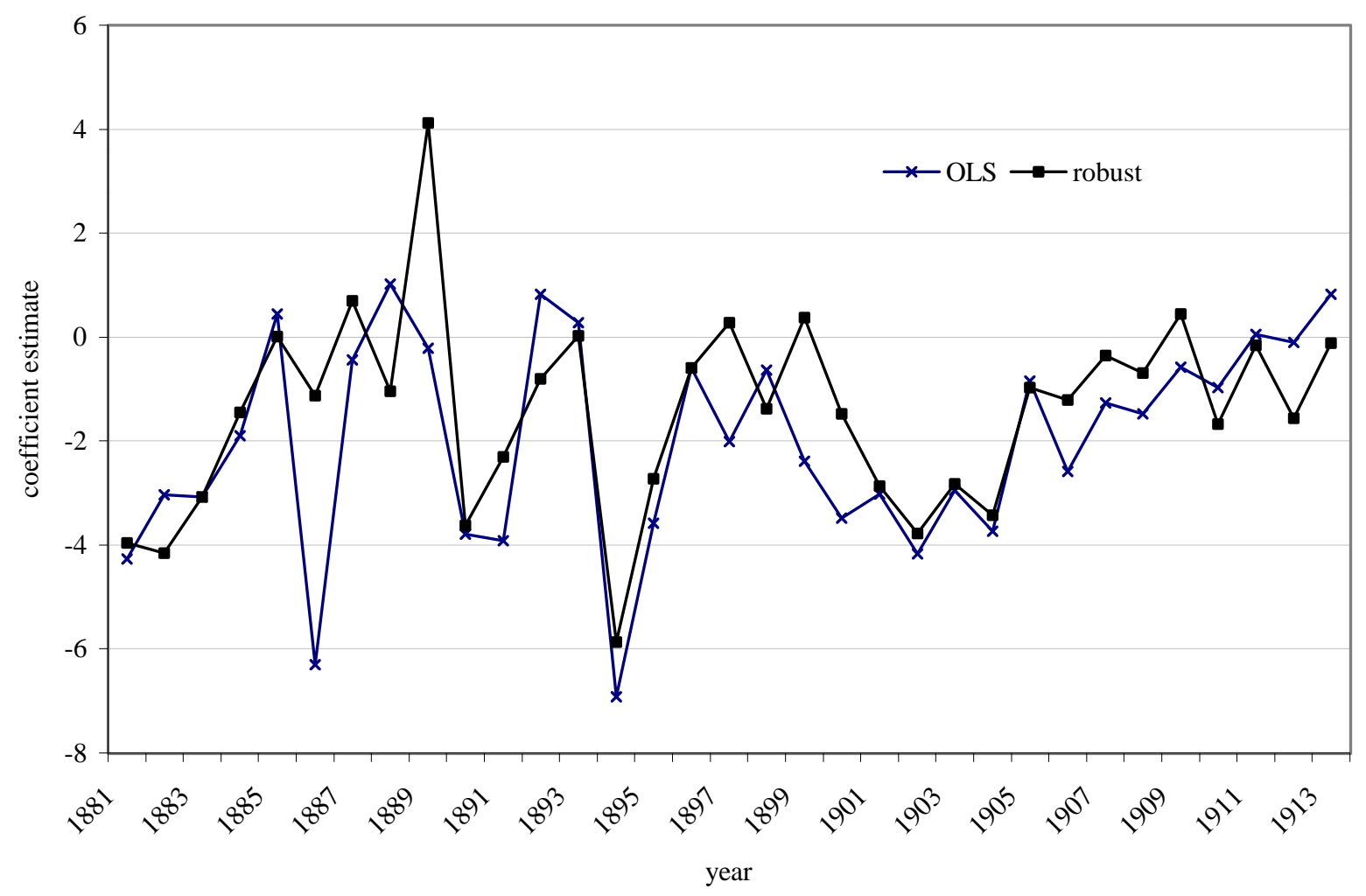

Figure 3. Robust Coefficient Estimates of Logged Market Equity. This figure presents the estimated coefficients on logged market equity from robust regressions of dividend-adjusted returns on beta, logged market equity, and logged book-to-market ratios. 


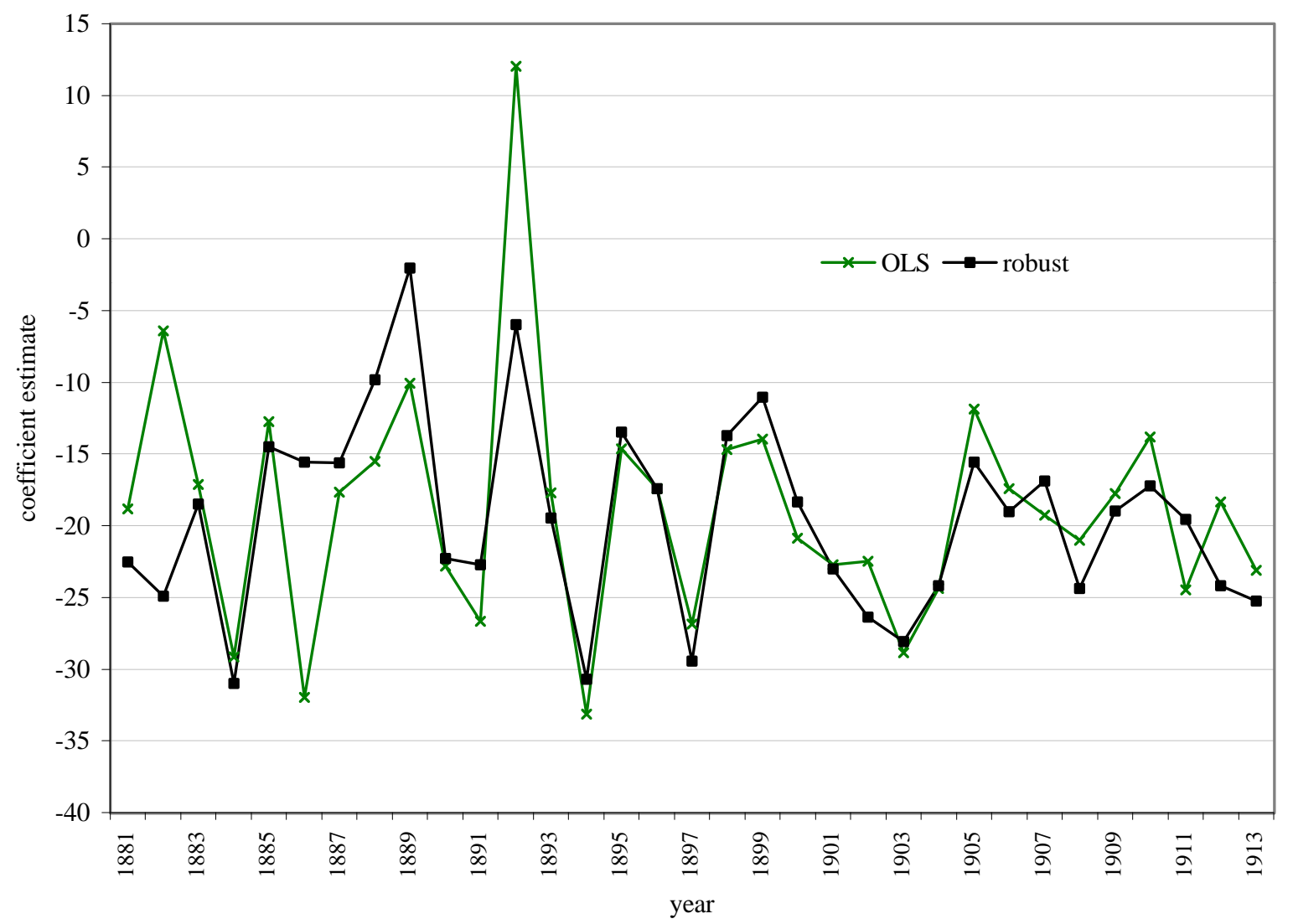

Figure 4. Robust Coefficient Estimates of Logged Market-to-Book Ratio. This figure presents the estimated coefficients on logged market-to-book ratio from robust regressions of dividend-adjusted returns on beta, logged market equity, and logged book-to-market ratios. 


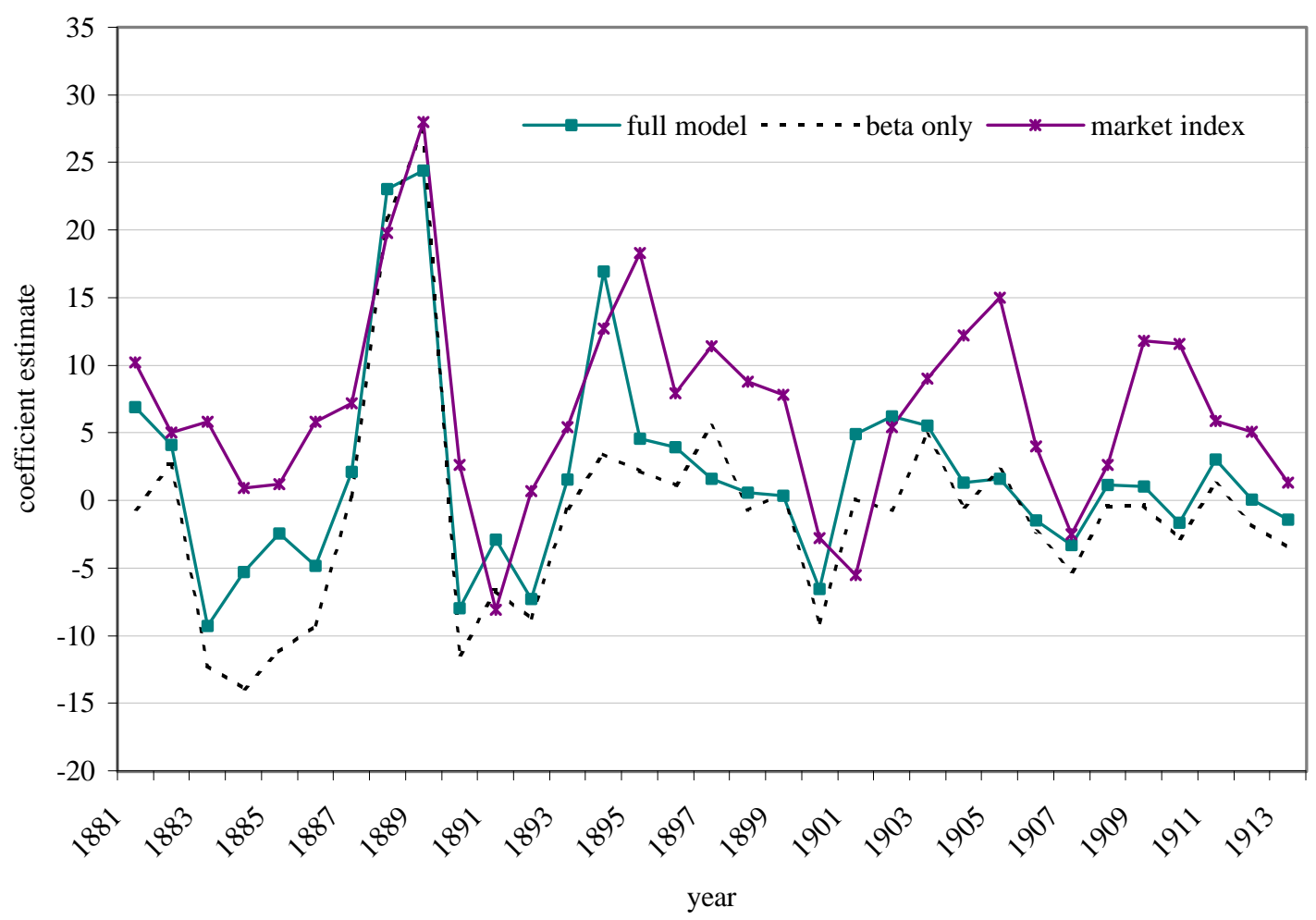

Figure 5. Robust Coefficient Estimates of Beta. This figure presents the estimated coefficients on beta from robust regressions of dividend-adjusted returns on beta, logged market equity, and logged book-to-market ratios. 


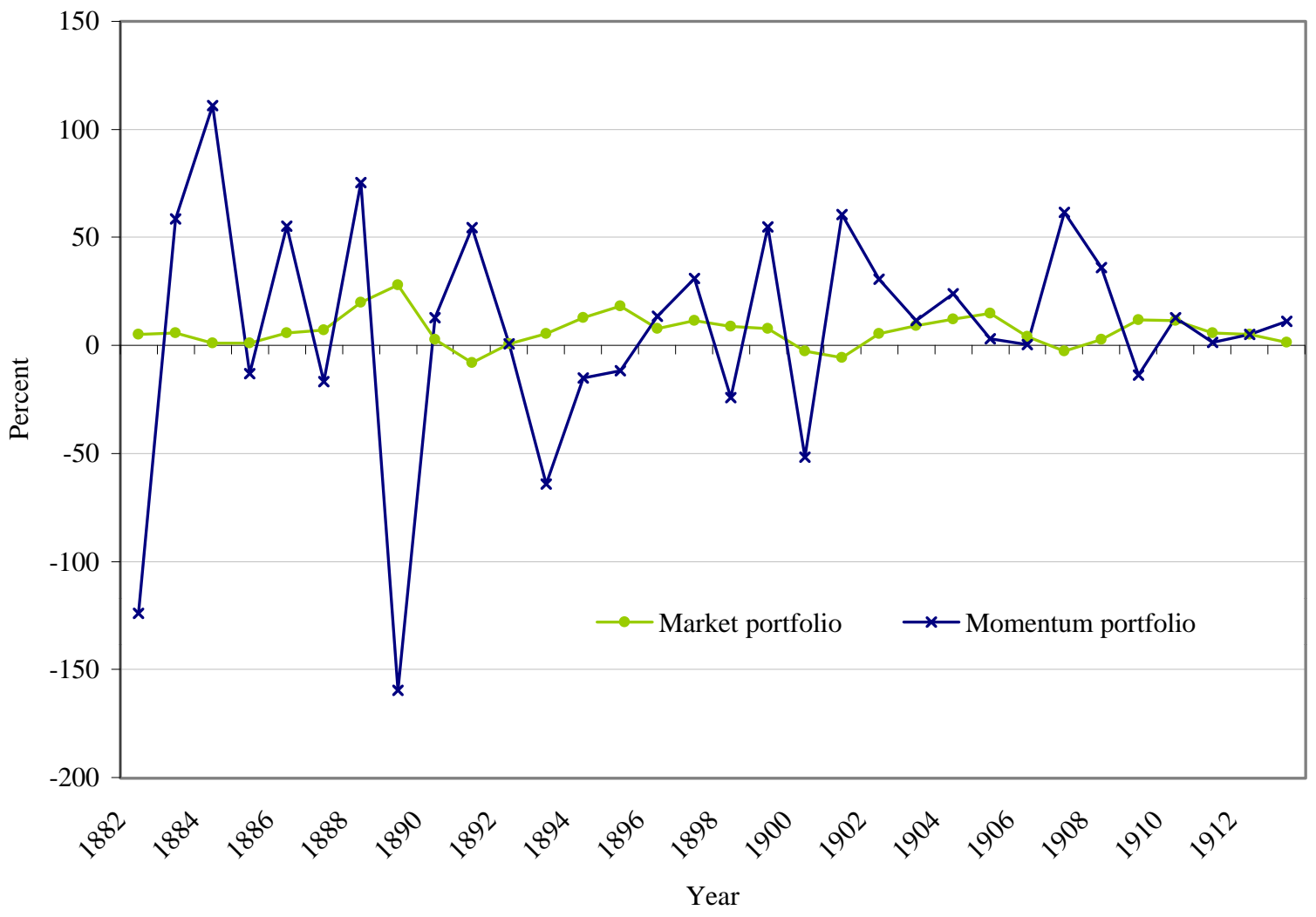

Figure 6. Return on Momentum Portfolio. This figure presents the dividendadjusted return on the momentum portfolio (long in top-20 percent; short in bottom-20 percent stocks using regression residuals) as well as the dividend-adjusted return on the 